\title{
Influence of aggregates grading and water/cement ratio in workability and hardened properties of mortars
}

\author{
Vladimir G. Haach ${ }^{1}$ \\ Graça Vasconcelos ${ }^{2}$ \\ Paulo B. Lourenço ${ }^{3}$
}

\begin{abstract}
Mortar is the material responsible for distribution of stresses in masonry structures. Knowledge about the fresh and hardened properties of mortar is fundamental to ensure a good performance of masonry walls. Water/cement ratio and aggregates grading are among several variables that influence physical and mechanical behaviour of mortars. An experimental program is presented in order to evaluate the influence of aggregates grading and water/cement ratio in workability and hardened properties of mortars. Eighteen compositions of mortar are prepared using three relations cement:lime:sand, two types of sand and three water/cement ratios. Specimens are analyzed through flow table test, compressive and flexural strength tests. Results indicate that the increase of water/cement ratio reduces the values of hardened properties and increases the workability. Besides, sands grading has no influence in compressive strength. On the other hand, significant differences in deformation capacity of mortars were verified with the variation of the type of sand. Finally, some correlations are presented among hardened properties and the compressive strength.
\end{abstract}

Key words: mortar, water/cement ratio, sand grading, masonry. 


\section{Introduction}

Mortar is one of the constituents of the composite anisotropic material denominated "masonry". Mortar is responsible for creating a uniform stress distribution correcting the irregularities of blocks and accommodating deformations associated to thermal expansions and shrinkage. In case of mortar, it is well known that its influence on compressive strength of masonry is much reduced. Steil et al. [1] observed an increase of $8.8 \%$ in the compressive strength of masonry prisms when increased $78 \%$ of the compressive strength of mortar. In other study, Cunha et al. [2] increased $400 \%$ of mortar compressive strength to obtain an increase of $20 \%$ in the compressive strength of masonry. On the other hand, mortar has a high influence in bond strength and deformability of masonry (Edgell and Haseltine [3]). According to the results pointed out by Vasconcelos and Lourenço [4] the deformability of masonry is clearly influenced by the material at the bed joints. Very distinct pre-peak behavior was found by considering dry saw unit-mortar interfaces, rough dry joints, lime mortar or dry clay resulting from sieving granitic soil. Mohamad et al. [5] also studied the deformation properties for the masonry composite through compressive tests in masonry prisms built with four distinct types of mortar. Authors concluded that mortar governs the non-linear behavior of masonry and have a large influence in the axial strain of masonry prisms. Besides, mortar was found to play an important role in the bond strength properties at the unit-mortar interfaces (Atkinson et al. [6], Amadio and Rajgelj [7], Roberti et al. [8], Binda et al. [9]). It is well accepted that bond strength is dependent on the unit and mortar properties and also on the moisture content of the unit at time of laying. Reddy and Gupta [10] observed the influence of sand grading in tensile bond strength of soil- 
cement block couplets. Authors observed in tests that there was 55-60\% reduction in tensile bond strength as fineness modulus of sand changes from 3.21 to 1.72 .

According to Sabatini [11] workability of mortars also plays an important role on the construction process of masonry structures. The workability may be considered one of the most important properties of mortar because it influences directly the bricklayer's work. It is important to mention that the quality of the workmanship can influence considerably the mechanical properties of masonry. The workability is an assembly of several properties such as consistency, plasticity and cohesion (Panarese et. al [12]). Given that plasticity and cohesion are difficult to measure, consistency is frequently used as the measure of workability.

Thus, based on past research, it should be mentioned that the study of fresh and hardened properties of mortar are important to better understand its influence in the behaviour of masonry structures.

Among several variables which influence the fresh and hardened behaviour of mortar, water/cement ratio (w/c) and aggregate properties can be point out. Traditionally, w/c ratio probably is the most important parameter within cement materials technology such as concrete and mortar. In case of concrete studies, it is known that the compressive strength varies inversely with the w/c ratio through the Abrams' generalization law. However, it should be mentioned that mortar and concrete are different materials with distinct structures, compositions and functions. There are few works evaluating the influence of w/c ratio in the strength of mortars. Appa Rao [13] evaluated the influence of the constituent materials and various mix proportions on compressive and splitting tensile strength of mortar and observed that the Abrams' generalized law is applicable to mortars with w/c ratio higher than 0.40. Markeset and Hillerborg [14] established some 
correlations between mechanical properties such as compressive strength, flexural strength and elastic modulus and several mortar mixes. It was also observed that a power function describes reasonably well the dependence of the compressive strength on the w/c ratio. The influence of the aggregates in mortar is not well documented as well. According to Neville [15] aggregates have a significant influence in both rheological and mechanical properties of mortars. Mineralogical composition, toughness, particle size distribution, shape and surface texture of aggregates are properties which affect the behaviour of mortars in fresh and hardened state. From test results, De Schutter and Poppe [16] noticed that sand type has a very significant influence on the mortar properties. Geometrical parameters based on the grading curve, like fineness modulus, relative specific surface and apparent weight, were correlated with the water demand of the sand in the mortar, influencing also the dry density of mortars. Westerholm et al. [17] observed that the fines content influences the viscosity of mortar, which may increase due to the increase in the total surface area of the fine aggregates. Additionally, Reddy and Gupta [10] noticed that to achieve a given consistency, the mortars using fine sand require 25 to 30\% more water. According to Reddy and Gupta [10] there are limited studies on the influence of sand grading on the characteristics of mortars.

For this purpose, the performance of different mortars is assessed in terms of workability and mechanical properties, using distinct w/c ratios and two different types of sand. A detailed discussion of all results is also provided. 


\section{Experimental Program}

The performance of distinct mortar compositions was evaluated based on experimental results related to the fresh and hardened state. The characterization of the fresh behavior was carried out based on the workability by measuring the consistency. The hardened behavior of mortar compositions was evaluated through the mechanical properties characterizing the compressive and flexural behavior.

For this experimental characterization, an enlarged experimental program was designed.

\section{Material Properties}

Portland cement, lime and sand were the materials used to prepare all mixes of mortars. The cement used was CEM II/B-L 32.5N, according to European standard EN 197-1 [18]. The natural hydraulic lime used is a commercial lime of class HL5, according to European standard EN 459-1 [19]. Three mixes of mortar were prepared keeping the same binder/aggregate ratio: 1:3 (Portland cement:sand), 1:0.5:4.5 (Portland cement:lime:sand) and 1:1:6 (Portland cement:lime:sand). For each mix, three different water-cement ratios (w/c) were considered. Two types of sand with distinct granulometry were used as aggregate. Sands were named as fine sand (FS) and coarse sand (CS), see Fig. 1. The fine sand has a fineness modulus of 1.8 and a maximum diameter of $2.35 \mathrm{~mm}$. And the coarse sand has a fineness modulus of 3.2 and a maximum diameter of $4.75 \mathrm{~mm}$. Some physical properties of materials are indicated in Table 1.

A total of 18 mortar mixes with fine and coarse sand grades were considered for the characterization of the compressive and flexural strength and modulus of elasticity, see 
Table 2. The water-cement ratios for all mixes were fixed based on the work performed previously (Mohamad et al. [20] and Haach et al. [21]).

\section{Test procedures}

The mixing of mortars was performed according to Brazilian standard NBR 9287 [22]. The binder and the water were mixed over a period of 30 seconds. This task was followed by the addition of sand in a period of 30 seconds with the mixer running in a low speed. After this period, the speed of mixer was increased and kept constant during 30 seconds. The mixer was stopped for a period of 90 seconds and restarted with high velocity for more 60 seconds.

The consistency of mortar was obtained by means of the flow table test according to European standard EN 1015-3 [23]. According to this European standard mortar should be introduced in the mould in two layers. Each layer is compacted with, at least, 10 short strokes to ensure uniform filling of the mould. After skimming off the excess of mortar and cleaning the free area of the test disc, the mould is raised vertically, being the mortar spread out on the disc by jolting the flow table 15 times at a constant frequency (approximately one per second). The flow value is the average of diameters of the spread mortar in the disc measured in two perpendicular directions. As aforementioned, the workability is the conjunction of properties like consistency and plasticity. However, in quantitative terms only the consistency is measured.

The analysis of the hardened behaviour of mortar mixes was carried out based on the results of experimental tests aiming at characterizing the compressive and flexural behavior. From the experimental tests information on the mechanical properties such as compressive and flexural strength and the elastic modulus was obtained. Compressive 
and flexural tests were carried out on prismatic specimens 40mmx40mmx160mm according to European standard EN 1015-11 [24], see Fig. 2a. A servo-controlled hydraulic machine was used for the compressive and flexural tests in prismatic specimens. The obtainment of stress-strain diagrams and the calculation of the elastic modulus was based on compressive tests carried out on cylinders with 50mm diameter and 100mm height (height to diameter ratio of 2), according to Brazilian standard NBR 13279 [25]. This test was not performed for mortars composed by medium sand. The vertical displacements of the cylindrical specimens were measured by means of three LVDTs attached $120^{\circ}$ apart to the specimens, see Fig. 2b. The strains of each specimen were obtained by averaging the three displacements recorded in the LVDTs. A total of three prismatic and three cylindrical samples were moulded for each mortar mix. Specimens were cured in laboratory environment and compressive and flexural tests were performed after 28 days of the construction of specimens.

\section{Experimental results and discussion}

\section{Workability of mortars (Consistency through flow table test)}

The values of consistency measured by flow table tests for all mortar mixes are shown in Fig. 3. The results exhibited an almost linear correlation between $w / c$ ratio and workability, as already observed by Chindaprasirt [26]. As expected, by adding water to the mortar mixes, higher consistency of mortars was achieved, even if its variation differs for each mix. This result is in agreement with results pointed out in literature stating that mortar mixes with lime need more water to reach the same consistency of mortar mixes without lime, which is essentially related to the smaller particles size found in lime than in cement and thus to higher specific surface of lime (Sébaibi et al. 
[27], Reddy and Gupta [10], Hendricks et al[28]). Thus, the increase of the amount of fine particles in lime leads to a higher water retention capacity, which is also a measure of the workability (Sébaibi et al. [27]).

The grading of sand appears also to influence considerably the water quantity needed to obtain the same consistency in case of cement mortar (1:3). The cement mortar mix with fine sand required a higher amount of water to reach the same consistency of the mortar mix manufactured with coarse sand. Similar trend was not observed in case of mortar mixes with lime. This behaviour can be attributed to the fact that the specific surface of the lime is too much higher than specific surface of the both sands. Thus, the increase of specific surface of the constituents of mortar caused by the replacement of coarse sand for fine sand is negligible in mortar mixes with lime. This result is in agreement to the one pointed out by Reddy and Gupta [10], which stated that water retentivity of cement mortar is sensitive to sand grading, in opposition to lime mortar, in which water retentivity is not affected by sand grading.

\section{Hardened Behavior of mortars}

As aforementioned, compressive tests were performed on two geometries of specimens, namely cylindrical and prismatic, according to NBR 13279 [25] and EN 1015-11 [24] respectively. The use of cylindrical specimens aimed to obtain the elastic modulus of mortar, as it is not adequate to obtain it with prismatic specimens, and to obtain also the complete stress-strain diagrams for the distinct mortar mixes.

In order to compare the diagrams stress vs. strain among the distinct mortar mixes the average stress vs. strain diagrams were defined. This was made by normalizing the stress vs. strain diagrams by dividing the stresses and strains by the maximum stress and 
maximum strain, respectively, achieving normalized stresses and strains. After this, average normalized diagrams were calculated based on the three specimens of the same mortar mix. Finally, an average normalized diagram were again converted into an average stress vs. strain diagram by multiplying the normalized stresses and strains by the stresses and strains of the three specimens of the same mortar mix. Fig. 4 presents the average stress $v s$. strain diagrams for all mortar mixes.

In order to standardize the results to compare the behaviour of the distinct mortars, elastic strain was defined as the strain at $30 \%$ of compressive strength, and ultimate strain was taken as the strain at $60 \%$ of compressive strength in descending branch of the stress vs. strain diagram. Ductility was calculated as the relation between the ultimate strain and the elastic strain. A summary of the experimental results is presented in Table 3.

\section{Compressive strength}

The compressive behavior of the distinct mortar mixes can be analyzed from the complete stress vs. diagrams and from the results shown in Table 3, where a comparison between compressive strength obtained in prismatic and cyclindrical specimens can be made. It is well known that shape of the specimen has considerable influence in the compressive strength. Shape effect in the compressive strength is a subject very well documented mainly considering concrete specimens (Torrenti et al. [29]; Markeset and Hillerborg [14]; Del Viso et al. [30]). Differences in the compressive strength due to the shape of specimens occur basically due to the slenderness of the samples (height to length ratio) and to the boundary restraint between the loading platens and the specimen. The experimental results of this study clearly indicated a difference between 
cylindrical $\left(f_{c}\right)$ and prismatic $\left(f_{p}\right)$ compressive strength of mortars, as observed also by Mohamad et al. [20]. Prismatic specimens exhibited a higher compressive strength, which is agreement with the conclusions of Del Viso et al. [30] and Stahli and Van Mier (2007), who observed that large specimens exhibit lower values of resistance than small specimens. An expressive linear fitting was observed between cylindrical and prismatic compressive strength with a high coefficient of correlation, see Fig. 5. From the results it was seen that compressive strength in cylindrical specimens is $11 \%$ higher than in prismatic specimens. A difference of about 5\% was found by Stahli and Van Mier [31] between prismatic and cylindrical specimens. It should be stressed that the experimental value obtained in the present work is close to the range suggested by Eurocode 2 [32] for concrete.

The dependence of the compressive strength on the variation of the $w / c$ ratio for the mortar mixes is shown in Fig. 6. A clear trend for the compressive strength decreases as the $w / c$ ratio increases was found for all mortar mixes. This result is in agreement to results pointed out by (Appa Rao [13]; Mohamad et al [20]; Fernandes et al. [33]). The increase in the $w / c$ ratio means that there is more water between the solid particles and consequently there are more voids in hardened condition, increasing porosity and consequently leading to the decrease on the compressive strength. Besides, from Fig. 4, it is possible to conclude that the increase in the lime amount in the mortar mix results in the considerable lowering of the compressive strength. In fact, in lime mortars higher amount of water should be added to attain a certain level of workability, meaning that higher porosity mortar mixes is achieved, see Fig. 7. As presented by Appa Rao [13]) a general variation of compressive strength with $w / c$ ratio can be proposed by following the Abram's law, for the designing of mortar mixes ranging from lean mortar mixes to 
very strong mortar mixes as a function of the single largest factor affecting the strength of mortar, which is the w/c ratio.

\section{Evaluation of the stress vs. strain diagrams}

The deformational behaviour of the distinct mortar mixes is evaluated based on the stress vs. strain diagrams obtained in the compressive tests on cylindrical specimens. From the average stress vs. strain diagrams, it is observed that the $w / c$ ratio influences not only the compressive strength, as discussed before, but also influences the elastic modulus and deformation capacity. The increase in the $w / c$ ratio results in the decrease of the elastic modulus and in the slight increase in the strain at peak stress, see Fig. 4. Similar trend was observed by Gonçalves et. al [34]. In spite of the scatter, it is clear that the trend for the decrease of the elastic modulus as the $w / c$ ratio increases is linear, see Fig. 8. This behaviour follows the trend for the compressive strength also decreases as the $w / c$ ratio increases.

Another variable that influences the deformability of mortars is the sand grading, even if its influence in the compressive strength is moderate, similarly to what was found by Curie and Sinha [35]. However, from the complete stress vs. strain diagrams, it is reasonably clear that sand grading influences the post-peak behaviour and ultimate deformation. Mortar mixes manufactured with coarse sand exhibit a more deformable and ductile behaviour. The post-peak branch of the stress vs. diagrams is clearly more smooth than in case of mortars with fine sands. This behaviour is probably due to the higher porosity of mortars with coarse aggregates and scattered structure caused by the non-uniform distribution of sand particles, see Fig. 7. Besides, specimens built with coarse sand presented higher deformation at peak stress, which was expected since the 
compressive strength of mortar built with coarse sand was also higher than compressive strength of mortars produced with fine sand.

It was also observed that sand grading influences, in a lesser extent than the $w / c$, the elastic modulus. This can be seen from the relation between elastic modulus and compressive strength for coarse and fine mortar mixes shown in Fig. 9. In spite of the high scatter of results, it is possible to conclude that elastic modulus depends on the compressive strength through a power function. It is possible also to state that mortar mixes manufactured with fine sand exhibit higher stiffness than mortars manufactured with coarse sand. This result is in agreement with the results pointed out by Reddy and Gupta [10]. Once more, this behaviour seems to be related to the non-uniform distribution of coarse sand particles, which influences the mortar skeleton. Finally, it should be underlined that mortars manufactured with lime presented a decrease in the compressive strength, even if the introduction of lime lead to higher deformation capacity in case of specimens built with coarse sand. From Table 3, it can be seen that ductility increases considerably in lime mortars, when compared to cement mortars.

\section{Flexural strength}

The relation between the flexural strength $\left(f_{t}\right)$ and the $w / c$ ratio for all evaluated mortar mixes is shown in Fig. 10. As in case of compressive strength and elastic modulus, flexural strength decreased with the increasing of $w / c$ ratio. Similarly to the relation between compressive strength and $w / c$ ratio, it was decided to define power function between flexural strength and the $w / c$ ratio, which is a reasonable correlation for specimens manufactured with fine sand. For the specimens with coarse aggregate 
mortars the scatter is considerable, being poor the coefficient of determination of the power correlation. This low correlation can be attributed to the insufficient amount of water required for hydration of cement particles in specimens of mortar mix 1:3 and $1: 1 / 2: 41 / 2$ with the lower $w / c$ ratio $(w / c=0.4$ and $w / c=0.9$, respectively), leading to incomplete compaction and consequently low flexural strength. Fig. 11 exhibits the surface of specimens manufactured with mortar mix 1:3 $(w / c=0.4)$ in comparison with mix 1:3 with a $w / c$ ratio of 0.8 . It is seen that the specimens manufactured with the lowest w/c ratio had no enough water to promote adequate hydration of cement particles. The author Appa Rao [13] also observed the limitation of using the value of 0.4 for the $w / c$ ratio related to the compaction capacity of the cement mortar mixes and admitted that Abrams' generalized water/cement ratio law is valid for mortars when the water/cement ratio is greater than 0.40 . Observing the results it can be concluded that there is a $w / c$ ratio lower bound value for each mortar composition after which compaction cannot be performed adequately.

On the contrary to the compressive strength, sands grading has a great influence in the flexural strength. Mortars manufactured with coarse sand exhibited higher flexural strength, with the exception of the mortar mix 1:1:6. Coarse sand probably promoted a better interlocking of particles due to the large sizes of grain, increasing the flexural strength. In mortar mixes 1:1:6 this behaviour was not observed possibly due to the increase of voids associated to the high amount of water required for cement hydration. As in case of elastic modulus, flexural strength was also correlated to prismatic compressive strength. A linear fitting seems to be the better approximation to related compressive strength and flexural strength, see Fig. 12. Results indicating that the 
flexural strength is around $30 \%$ of the value of prismatic compressive strength. Sands grading exhibited a very small influence on this relation.

\section{Conclusions and final remarks}

This work dealt with the experimental characterization of distinct mortar mixes with distinct composition, water/cement ratios and sand grading, in fresh and hardened conditions, based on consistency (flow table tests), and on compressive and flexural tests. From the analysis of experimental results, the main following conclusion can be drawn:

(a) Consistency of mortar increased with the increase of $w / c$ ratio and with introduction of lime. However, sands grading only influenced the consistency of mortars without lime. Mortars manufactured with fine sands exhibited lower consistency due to the higher amount of water required to wet the solid particles;

(b) All evaluated hardened properties (compressive strength, elastic modulus and flexural strength) decreased with the increase of $w / c$ ratio;

(c) Cylindrical compressive strength can be estimated as $90 \%$ of the prismatic compressive strength;

(d) Sands grading seemed not influenced the compressive strength. However, it influences the deformations, ductility and elastic modulus of mortars. Coarse sand exhibited more deformable and ductile behaviour and a lower elastic modulus, probably due to the sparse structure of these mortars caused by the non-uniform distribution of sand particles;

(e) Compressive and flexural strength follows the Abram's law with reasonable power fitting with w/c ratio; 
(f) Flexural strength can be estimated as $30 \%$ of the prismatic compressive strength.

\section{Acknowledgements}

This work was partly supported by contract DISWALL - “Development of innovative systems for reinforced masonry walls” - COOP-CT-2005-018120 from the European Commission. The first author was supported by the Programme Al $\beta a n$, the European Union Programme of High Level Scholarships for Latin America, Scholarship $n^{0}$ E06D100148BR. 


\section{References}

[1] Steil, R. O., Calçada, L. M. L, Oliveira, A. L., Martins, V. C., Prudêncio Jr, L. R.. "Influência do tipo de argamassa no fator de eficiência e na deformabilidade de alvenarias de blocos de concreto”. In: Anais do IV Simpósio Brasileiro de Tecnologia de Argamassas, Brasília, 2001, p.423-434. (in portuguese)

[2] Cunha, E. H., Guimarães, G. N., Carasek, H.. "Influência do tipo de argamassa na resistência à compressão da alvenaria estrutural”. In: Anais do IV Simpósio Brasileiro de Tecnologia de Argamassas, Brasília, 2001, p.397-408. (in portuguese)

[3] Edgell, G., Haseltine, B.A.. "Building mortar for low rise housing recommendations, problems and solutions", British Masonry Society Publication, 2005, pp.29.

[4] Vasconcelos, G., Lourenço, P.B.. “Experimental characterization of stone masonry in shear and compression”, Construction and Building Materials, 23(11), 2009, p. 33373345.

[5] Mohamad, G., Lourenço, P. B.; Roman, H. R.. "Mechanics of hollow concrete block masonry prisms under compression: Review and prospects”, Cement \& Concrete Composites, V. 29 (3), 2007, p.181-192.

[6] Atkinson, R. H., Amadei, B. P. , Saeb, S., Sture, S.. "Response of masonry bed joints in direct shear”, Journal of Structural Engineering; V. 115(9), 1989, p. 2277-2296.

[7] Amadio C, Rajgelj S.. "Shear behavior of brick-mortar joints", Masonry International; V. 5(1), 1999, p. 19-22

[8] Roberti, G. M., Binda, L., Cardani, G.. "Numerical modeling of shear bond tests on small brick-masonry assemblages”, Computer Methods in Structural Masonry - 4, Florence, Italy; 1997, p. 145-152. 
[9] Binda, L., Tiraboschi, C., Abbaneo, S.. "Experimental research to characterize masonry materials”, Masonry International; V. 10(3), 1997, p. 592-101.

[10] Reddy, B. V. V., Gupta, A.. "Influence of sand grading on the characteristics of mortars and soil-cement block masonry”, Construction and Building Materials, V. 22 (8), 2008, p.1614-1623.

[11] Sabatini, F. H., "O processo construtivo de edifícios de alvenaria estrutural sílicocalcário”, Thesis of Master of Science, University of São Paulo, São Paulo, 1984.

[12] Panarese, W. C., Kosmatka, S. H., Randall, F. A., "Concrete masonry handbook for architects, engineers, builders”, Portland Cement Association, 5th ed., USA, 1991. [13] Appa Rao, G.. " Generalization of Abrams' law for cement mortars”, Cement and Concrete Research, V. 31(3), 2001, p.495-502.

[14] Markeset, G., Hillerborg, A.. "Softening of concrete in compression — localization and size effects”, Cement and Concrete Research, V.25(4), 1995, 702-708.

[15] Neville, A.M.. Properties of Concrete, Fourth edition, John Wiley \& Sons Inc., New York, 1996.

[16] De Schutter, G., Poppe, A. M.. "Quantification of the water demand of sand in mortar”, Construction and building materials, V. 18 (7), 2004, p.517-521.

[17] Westerholm, M., Lagerblad, B., Silfwerbrand, J., Forssberg, E.. " Influence of fine aggregate characteristics on the rheological properties of mortars”, Cement and Concrete Composites, V. 30 (4), 2008, p.274-282.

[18] EUROPEAN STANDARD. EN 197-1, Cement. Compositions, specifications and conformity criteria for common cement, 2000.

[19] EUROPEAN STANDARD. EN 459-1, Building lime: Part 1. Definition, specification and conformity criteria, 2001. 
[20] Mohamad, G., Lourenço, P.B., Camões, A, Roman, H.R., Estudo de caracterização mecânica das argamassas de assentamento para alvenaria estrutural, VII Simpósio Brasileiro de Tecnologia das Argamassas - VII SBTA, Recife, Brasil, 2007.

[21] Haach, V.G., Vasconcelos, G., Lourenço, P.. "Composition study of a mortar appropriate for masonry cavities and joints", Proceedings of the 10th North American masonry Conference, St. Louis, Missouri, USA, 2007.

[22] ASSOCIAÇÃO BRASILEIRA DE NORMAS TÉCNICAS (ABNT). NBR 9287, Argamassa para assentamento para alvenaria de blocos de concreto. Determinação da retenção de água, Rio de Janeiro, 1984.

[23] EUROPEAN STANDARD. EN 1015-3, Methods of test for mortar for masonry: Part 3: Determination of consistency of fresh mortar (by flow table). (1999)

[24] EUROPEAN STANDARD. EN 1015-11, Methods of test for mortar for masonry: Part 11: Determination of flexure and compressive strength of hardened mortar, 1999. [25] ASSOCIAÇÃO BRASILEIRA DE NORMAS TÉCNICAS (ABNT). NBR 13279, Argamassa para assentamento de paredes e revestimentos de paredes e tetos. Determinação da resistência à compressão. Rio de Janeiro, 1995.

[26] Chindaprasirt, P., Buapa, N., Cao, H. T.. " Mixed cement containing fly ash for masonry and plastering work”, Construction and building materials, V. 19 (8), 2005, p.612-618.

[27] Sébaïbi, Y., Dheilly, R.M., Quéneudec, M. "Study of the water-retention capacity of a lime-sand mortar: Influence of the physicochemical characteristics of the lime”, Cement and Concrete Research, V. 3(5), 2003, p. 689-696. 
[28] Hendricks, R., Roels, S., Van Balen, K. "Measuring the water capacity and transfer properties of fresh mortar”, Cement and Concrete Research, V. 40(12), 2010, p. 16501655.

[29] Torreti, J.M., Benaija, E.H., Boulay, C.. "Influence of boundary conditions on strain softening in concrete compression tests”, Journal of Engineering Mechanics, V.119(12), 1993, 2369-2384.

[30] Del Viso, J. R., Carmona, J. R., Ruiz, G.. "Shape and size effects on the compressive strength of high-strength concrete”, Cement and Concrete Research, V.38(3), 2008, 386-395.

[31] Stahli, P., Van Mier, Jan G.M.. "Manufacturing, fibre anisotropy and fracture of hybrid fibre concrete”, Engineering Fracture Mechanics, V. 74(1-2), 2007, p. 223-242.

[32] EUROPEAN STANDARD Eurocode 2: Design of concrete structures - Part 1: General rules and rules for buildings, 2002.

[33] Fernandes, V., Silva, L., Ferreira, V. M., Labrincha, J. A.. "Evaluation of mixing and application process parameters of single-coat mortars”, Cement and Concrete Research, V. 35 (5), 2005, p.836-841.

[34] Gonçalves, J. P., Tavares, L. M., Toledo Filho, R. D., Fairbairn, E. M. R., Cunha, E. R.. "Comparison of natural and manufactured fine aggregates in cement mortars", Cement and Concrete Research, V. 37 (6), 2007, p.924-932.

[35] Currie, D., Sinha, B.P.. Survey of Scottish sands and their characteristics which

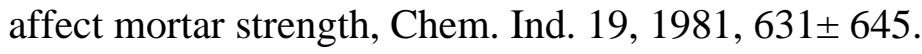




\section{List of captions for illustrations}

Fig. 1 - Particle size distribution of sands.

Fig. 2 - Details of the experimental tests: (a) flexural tests in prismatic specimens and

(b) compressive test in cylinder specimens.

Fig. 3 - Diagram Flow table vs. water/cement ratio.

Fig. 4 - Medium diagrams stress vs. strain: (a) fine sand and (b) coarse sand.

Fig. 5 - Correlation between prismatic and cylindrical compressive strength.

Fig. 6 - Diagram compressive strength vs. water/cement ratio: (a) prismatic samples and (b) cylindrical samples.

Fig. 7 - Failure surface of mortars specimens under compression $(1: 3, \mathrm{w} / \mathrm{c}=0.80)$ :

(a) fine sand and (b) coarse sand.

Fig. 8 - Relation between secant elastic modulus and water/cement ratio.

Fig. 9 - Relation between compressive strength and secant elastic modulus.

Fig. 10 - Diagram flexural strength vs. water/cement ratio.

Fig. 11 - Differences between specimens surfaces due to compaction capacity: (a) mix $1: 3, \mathrm{w} / \mathrm{c}=0.80$, fine sand and (b) $\operatorname{mix} 1: 3, \mathrm{w} / \mathrm{c}=0.40$, coarse sand.

Fig. 12 - Relation between flexural strength and compressive strength. 
Table 1 - Properties of materials

\begin{tabular}{ccccc}
\hline Property & Cement & Lime & Fine Sand & Coarse Sand \\
\hline Density $(\mathrm{kg} / \mathrm{m} 3)$ & 3210 & 2720 & 2640 & 2640 \\
\hline Unit mass $(\mathrm{kg} / \mathrm{m} 3)$ & 1080 & 760 & 1450 & 1660 \\
\hline
\end{tabular}


Table 2 - Mixes and corresponding water/cement ratios

\begin{tabular}{ccc}
\hline Mix & Aggregate & Water/cement ratios \\
\hline \multirow{2}{*}{$1: 3($ no lime) $)$} & Fine sand & $0.6,0.8,1.0$ \\
\cline { 2 - 3 } & Coarse sand & $0.4,0.6,0.8$ \\
\hline \multirow{2}{*}{$1: 1 / 2: 41 / 2$} & Fine sand & $1.1,1.3,1.5$ \\
\cline { 2 - 3 } & Coarse sand & $0.9,1.1,1.3$ \\
\hline \multirow{2}{*}{$1: 1: 6$} & Fine sand & $1.7,1.9,2.1$ \\
\cline { 2 - 3 } & Coarse sand & $1.5,1.7,1.9$ \\
\hline
\end{tabular}


Table 3 - Summary of mean values of experimental results.

\begin{tabular}{|c|c|c|c|c|c|c|c|c|c|c|}
\hline Mix & Sand & $w / c$ & $\begin{array}{l}\text { Cylindrical } \\
\text { Compressive } \\
\text { Strength } \\
\text { (MPa) }\end{array}$ & $\begin{array}{c}\text { Prismatic } \\
\text { Compressive } \\
\text { Strength } \\
\text { (MPa) }\end{array}$ & $\begin{array}{l}\text { Flexural } \\
\text { Strength } \\
\text { (MPa) }\end{array}$ & $\begin{array}{l}\text { Elastic } \\
\text { Modulus } \\
\text { (GPa) }\end{array}$ & $\begin{array}{c}\text { Elastic } \\
\text { Strain } \\
(\% 0)\end{array}$ & $\begin{array}{c}\text { Peak } \\
\text { Strain } \\
(\%)\end{array}$ & $\begin{array}{c}\text { Ultimate } \\
\text { Strain } \\
(\%)\end{array}$ & Ductility \\
\hline \multirow{6}{*}{$\begin{array}{c}1: 3 \\
\text { (no lime) }\end{array}$} & \multirow{3}{*}{$\begin{array}{l}\text { Fine } \\
\text { sand }\end{array}$} & 0.6 & 12.29 & 14.26 & 3.63 & 16.53 & 0.19 & 2.09 & 5.80 & 30.53 \\
\hline & & 0.8 & 8.39 & 10.69 & 3.30 & 12.07 & 0.13 & 1.34 & 4.15 & 31.93 \\
\hline & & 1.0 & 7.31 & 8.18 & 2.72 & 8.88 & 0.19 & 1.65 & 7.16 & 37.68 \\
\hline & \multirow{3}{*}{$\begin{array}{c}\text { Coarse } \\
\text { sand }\end{array}$} & 0.4 & 16.54 & 19.54 & 2.93 & 11.30 & 0.18 & 2.04 & 5.04 & 27.99 \\
\hline & & 0.6 & 13.40 & 14.01 & 5.15 & 12.78 & 0.33 & 2.18 & 5.00 & 15.16 \\
\hline & & 0.8 & 8.11 & 10.41 & 3.79 & 7.54 & 0.20 & 1.74 & 4.48 & 22.40 \\
\hline \multirow{6}{*}{$1: 1 / 2: 41 / 2$} & \multirow{3}{*}{$\begin{array}{l}\text { Fine } \\
\text { sand }\end{array}$} & 1.1 & 6.49 & 6.66 & 2.06 & 9.10 & 0.14 & 1.39 & 3.37 & 24.07 \\
\hline & & 1.3 & 5.49 & 5.13 & 1.84 & 7.98 & 0.11 & 1.22 & 3.65 & 33.18 \\
\hline & & 1.5 & 3.92 & 4.36 & 1.70 & 5.08 & 0.20 & 1.65 & 7.03 & 35.12 \\
\hline & \multirow{3}{*}{$\begin{array}{c}\text { Coarse } \\
\text { sand }\end{array}$} & 0.9 & 9.53 & 7.42 & 2.06 & 9.50 & 0.23 & 2.85 & 6.91 & 30.04 \\
\hline & & 1.1 & 7.03 & 8.40 & 2.94 & 9.63 & 0.10 & 1.82 & 6.52 & 65.20 \\
\hline & & 1.3 & 3.73 & 6.36 & 1.96 & 6.92 & 0.07 & 1.51 & 6.65 & 95.00 \\
\hline \multirow{6}{*}{ 1:1:6 } & \multirow{3}{*}{$\begin{array}{l}\text { Fine } \\
\text { sand }\end{array}$} & 1.7 & 2.80 & 3.63 & 1.42 & 4.84 & 0.09 & 1.00 & 3.61 & 40.11 \\
\hline & & 1.9 & 2.38 & 4.49 & 1.80 & 4.02 & 0.07 & 0.88 & 3.44 & 49.14 \\
\hline & & 2.1 & 1.91 & 2.68 & 1.15 & 3.28 & 0.11 & 1.10 & 3.70 & 33.64 \\
\hline & \multirow{3}{*}{$\begin{array}{c}\text { Coarse } \\
\text { sand }\end{array}$} & 1.5 & 6.06 & 5.35 & 1.63 & 10.16 & 0.09 & 1.54 & 8.90 & 98.89 \\
\hline & & 1.7 & 4.82 & 4.33 & 1.27 & 6.65 & 0.11 & 1.71 & 11.02 & 100.18 \\
\hline & & 1.9 & 3.54 & 3.10 & 0.95 & 3.73 & 0.15 & 2.16 & 10.58 & 70.53 \\
\hline
\end{tabular}




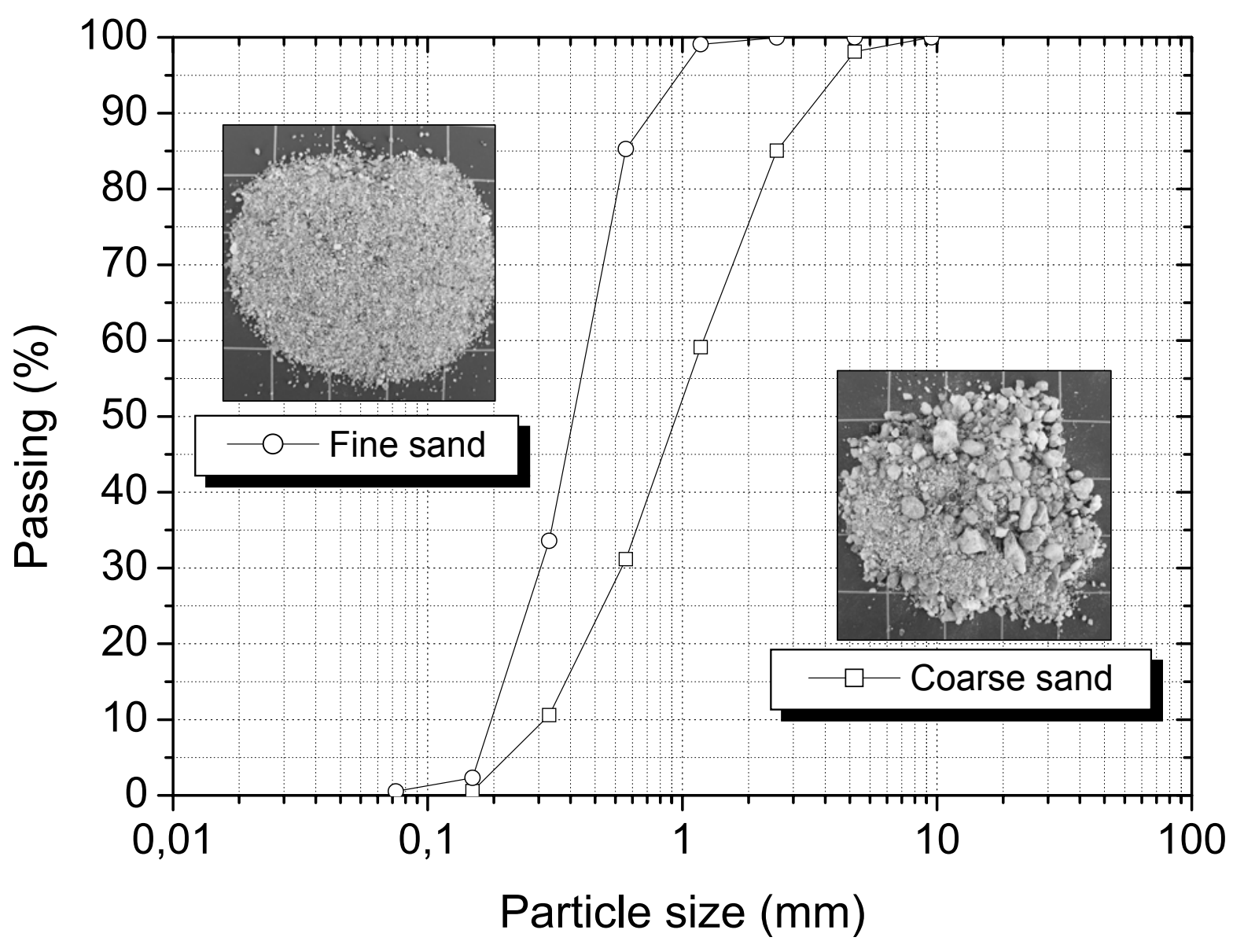




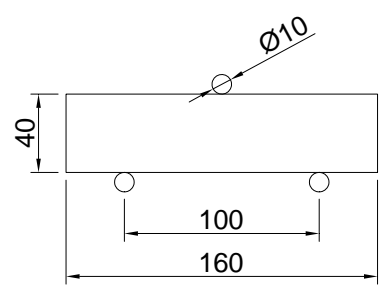

(a)
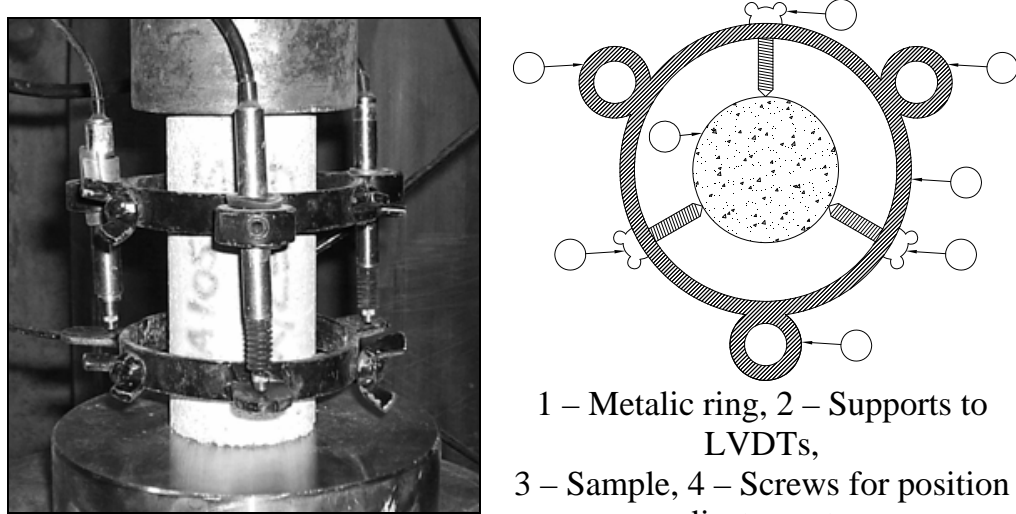

1 - Metalic ring, 2 - Supports to LVDTs,

3 - Sample, 4 - Screws for position adjustements.

(b) 


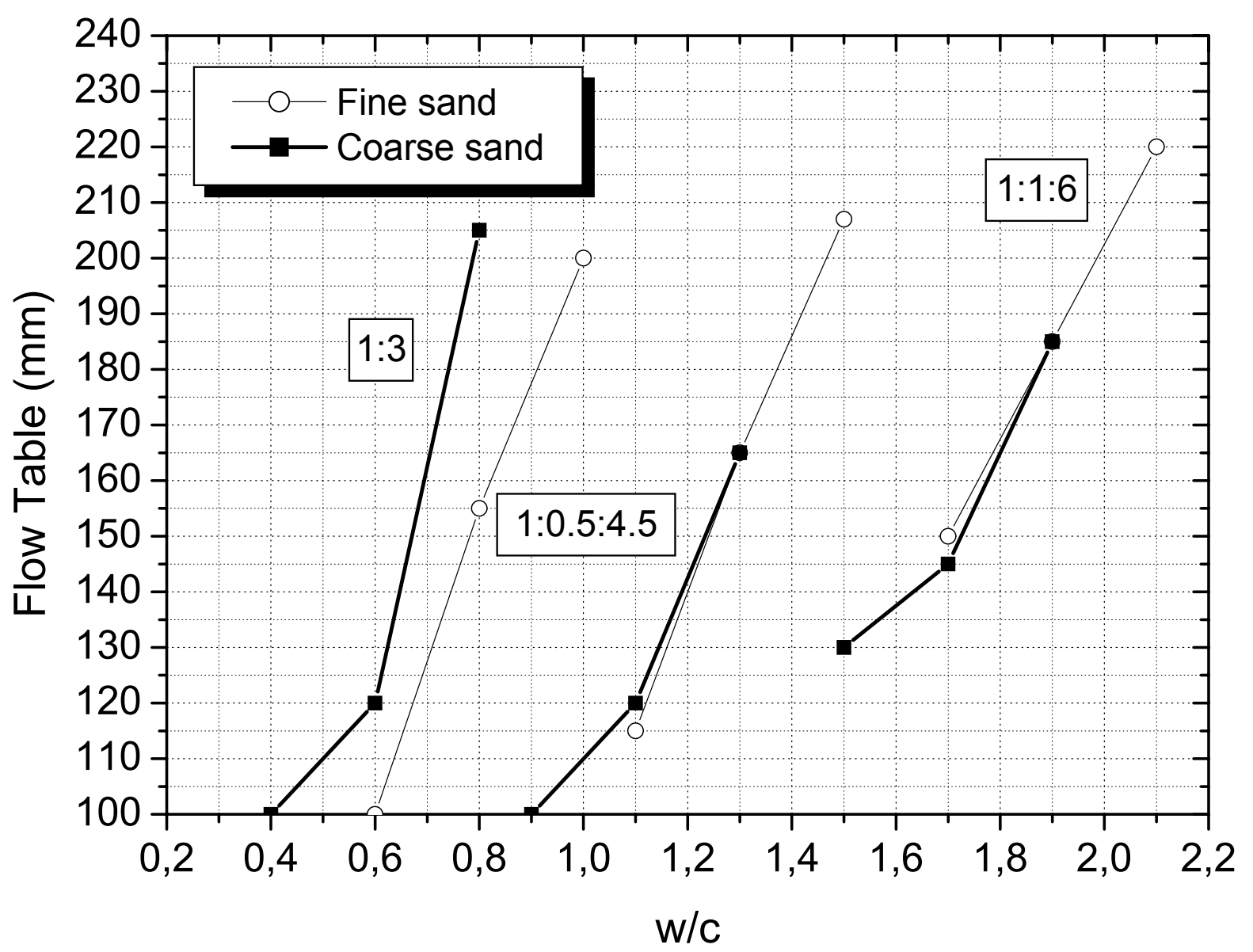




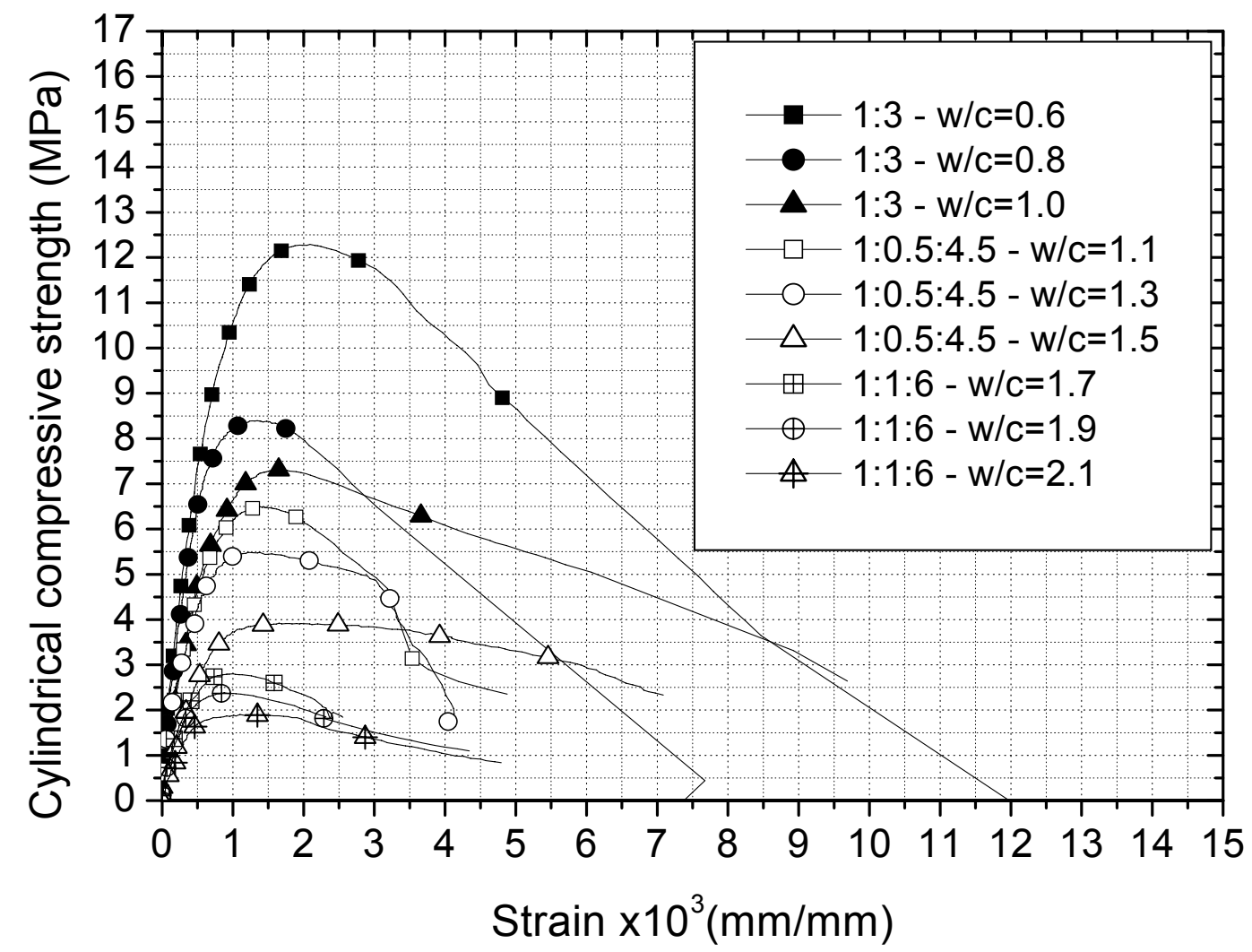

(a)

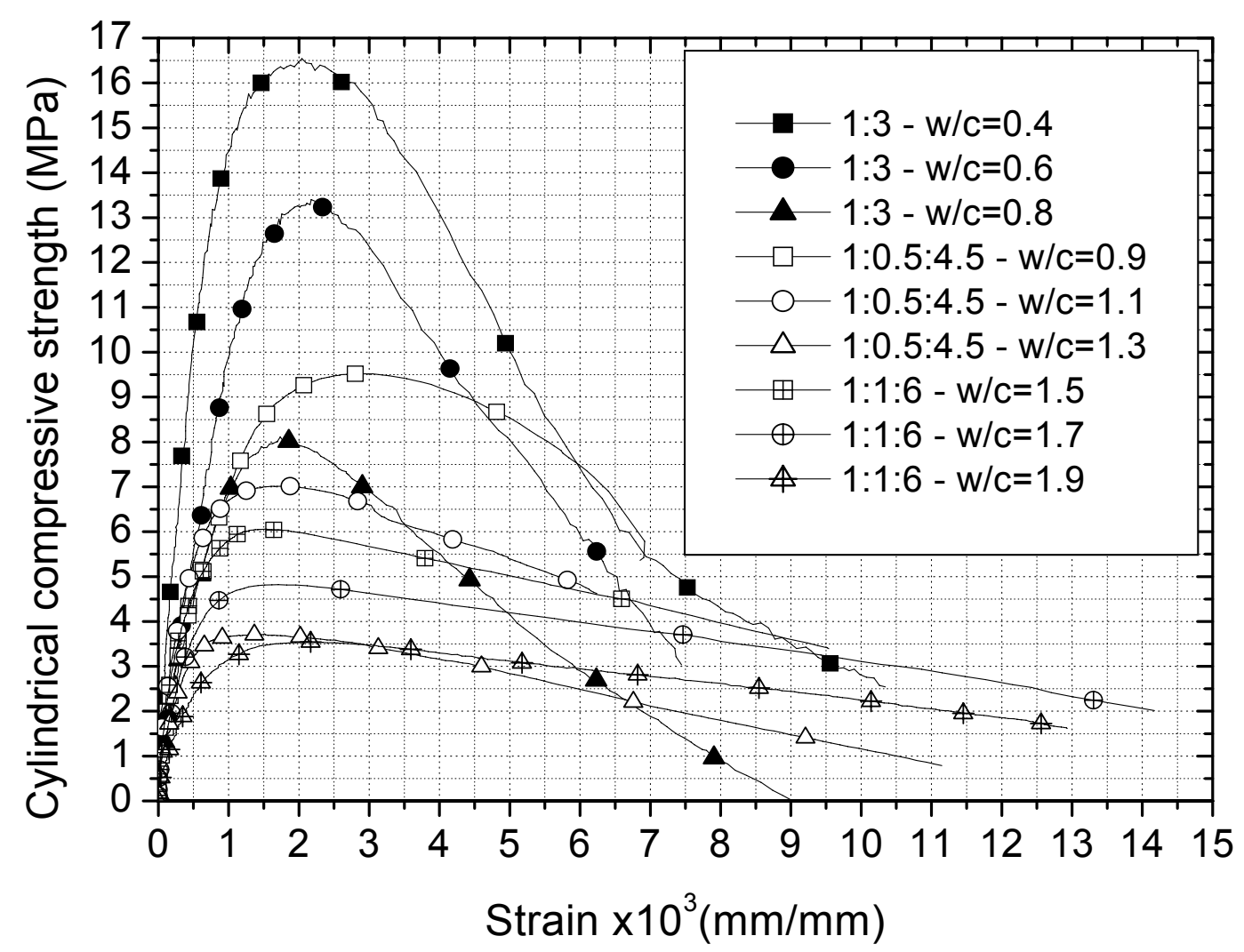

(b) 


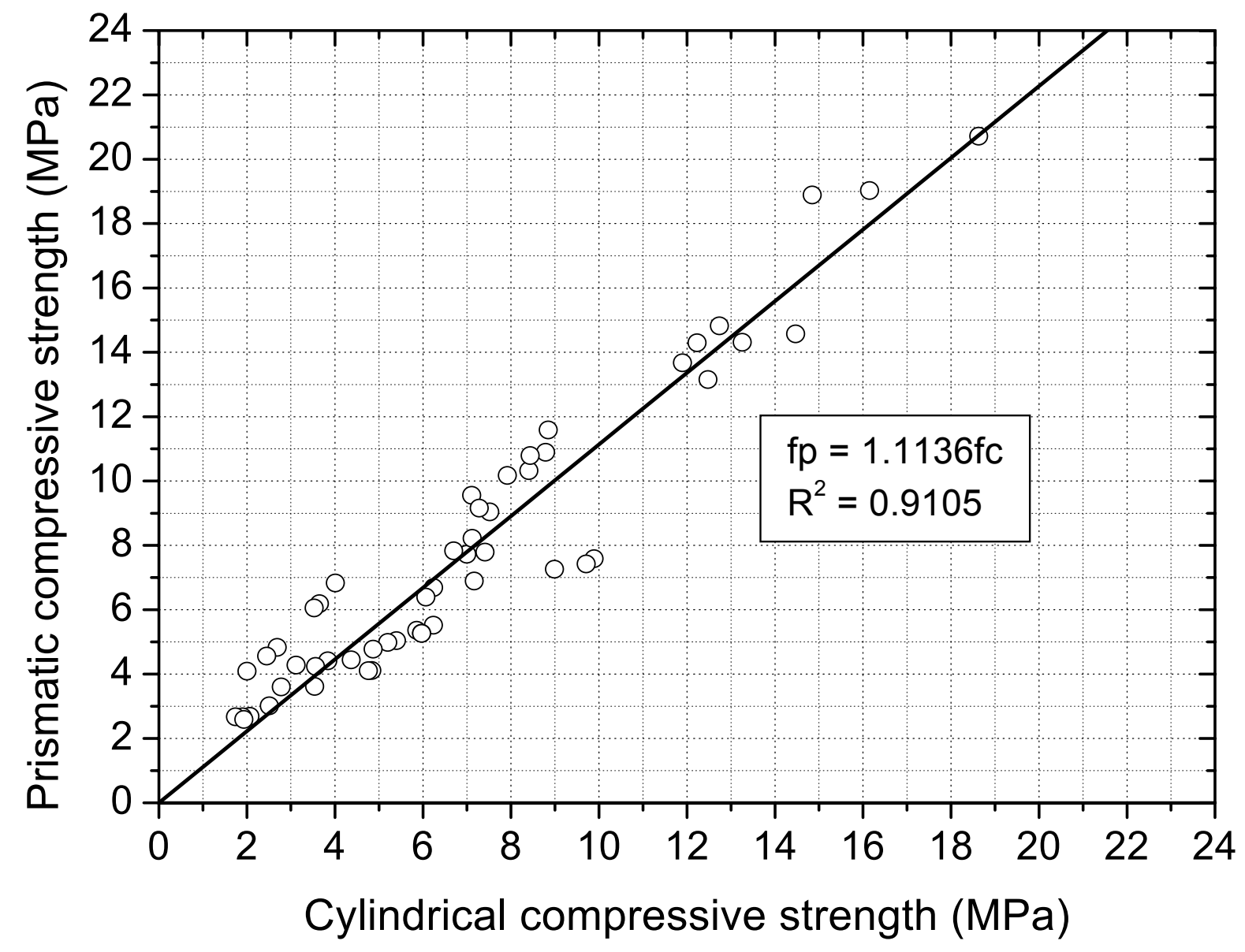




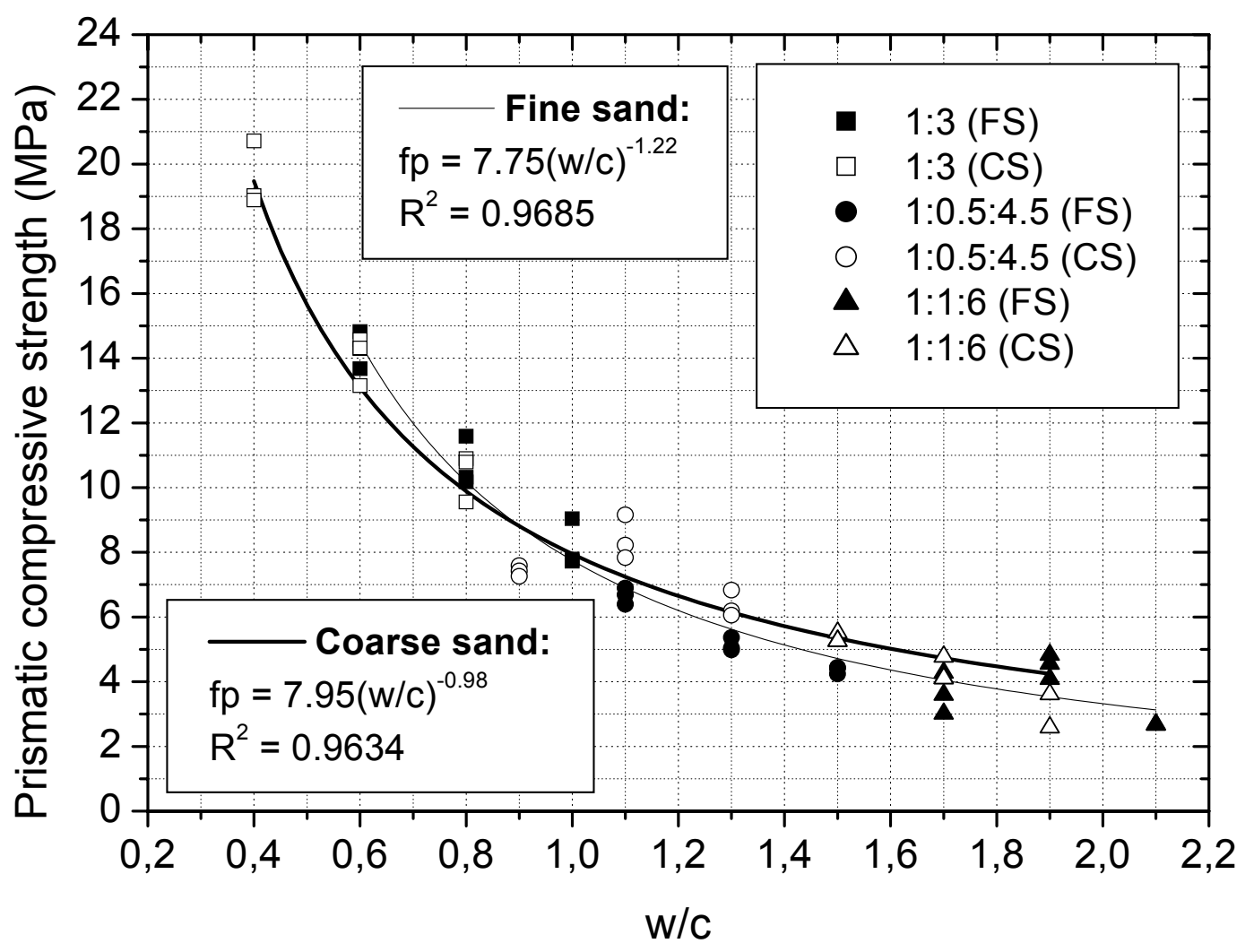

(a)

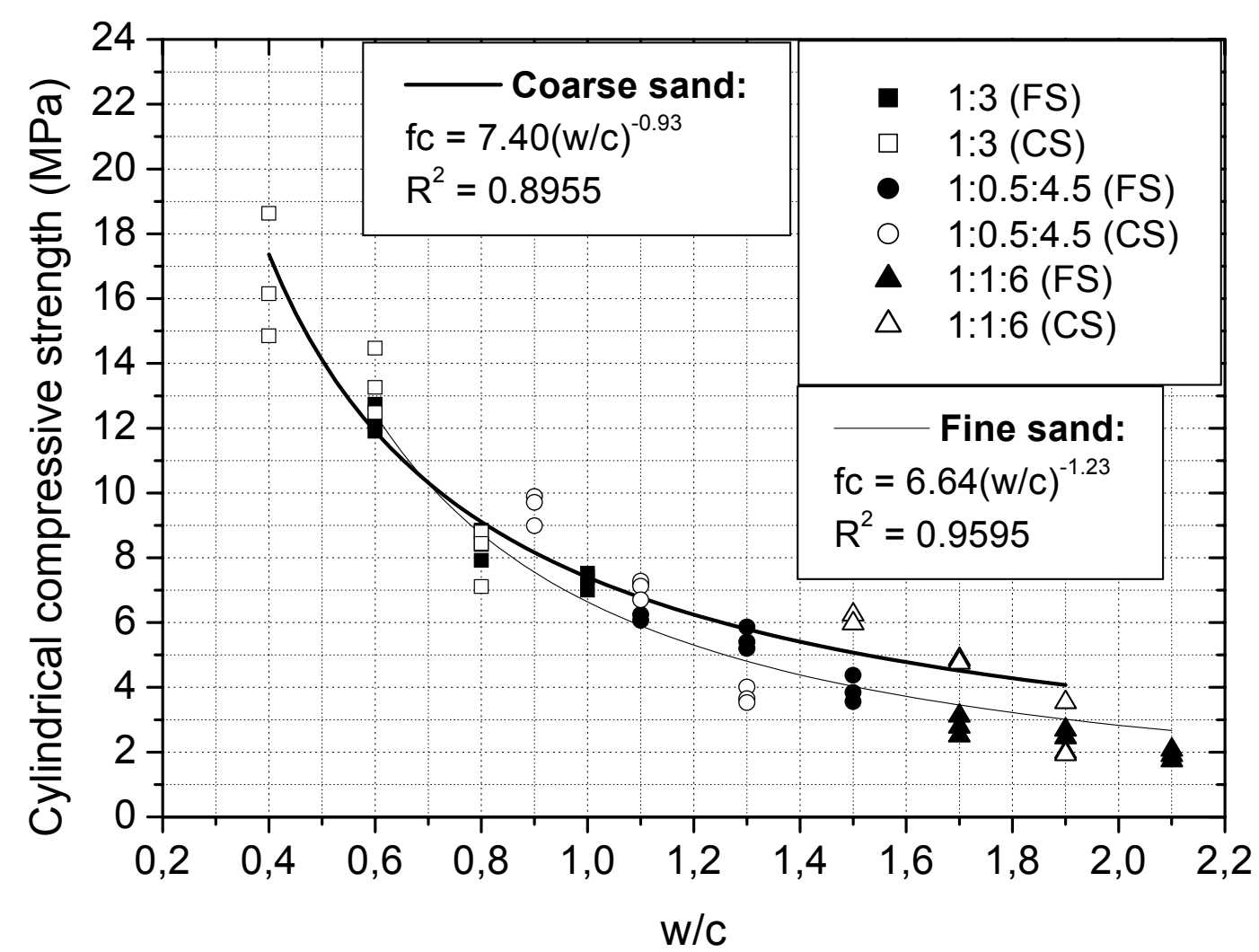

(b) 


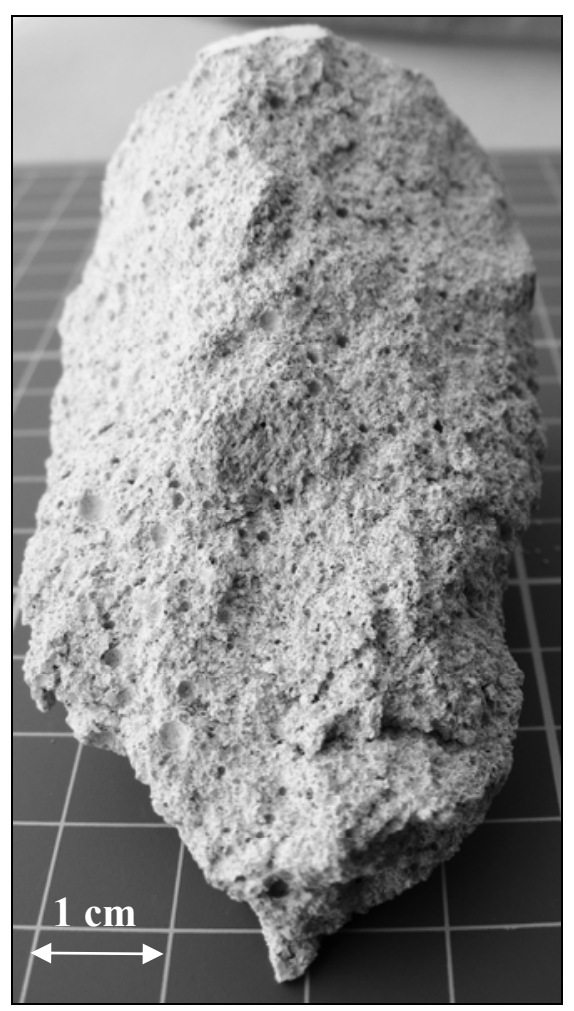

(a)

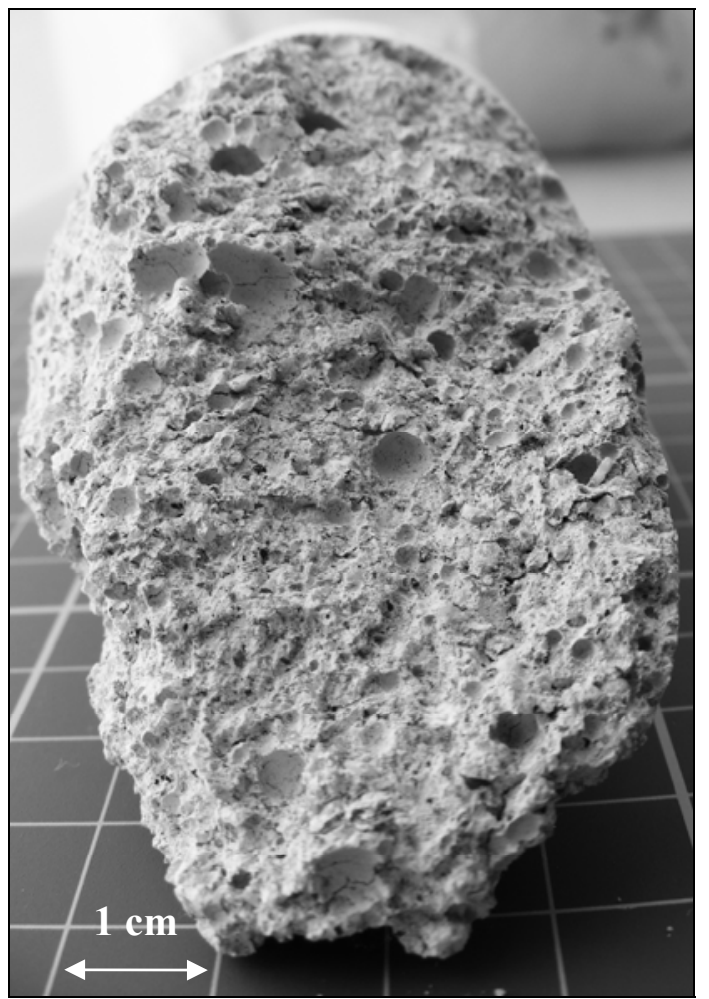

(b) 


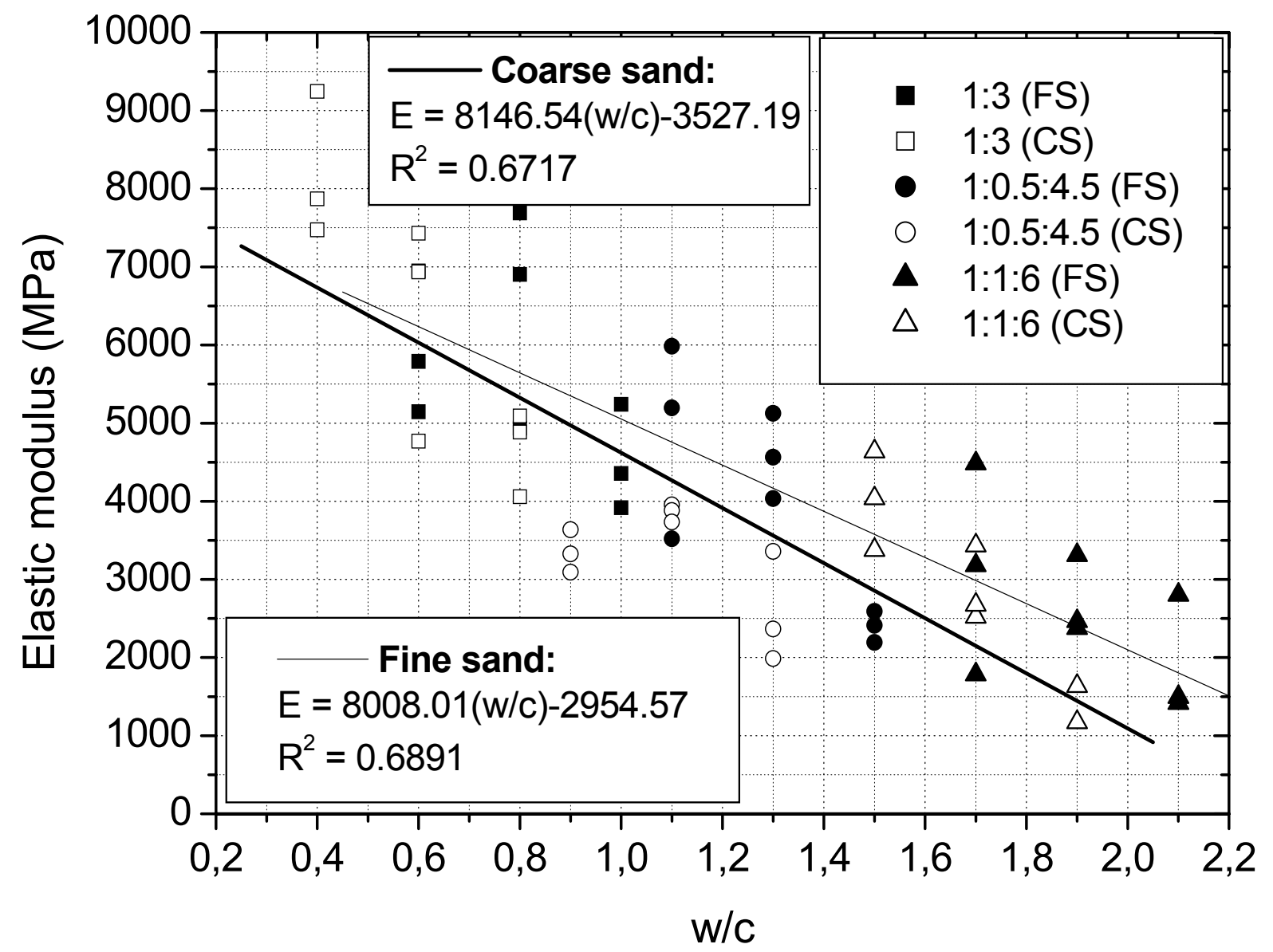




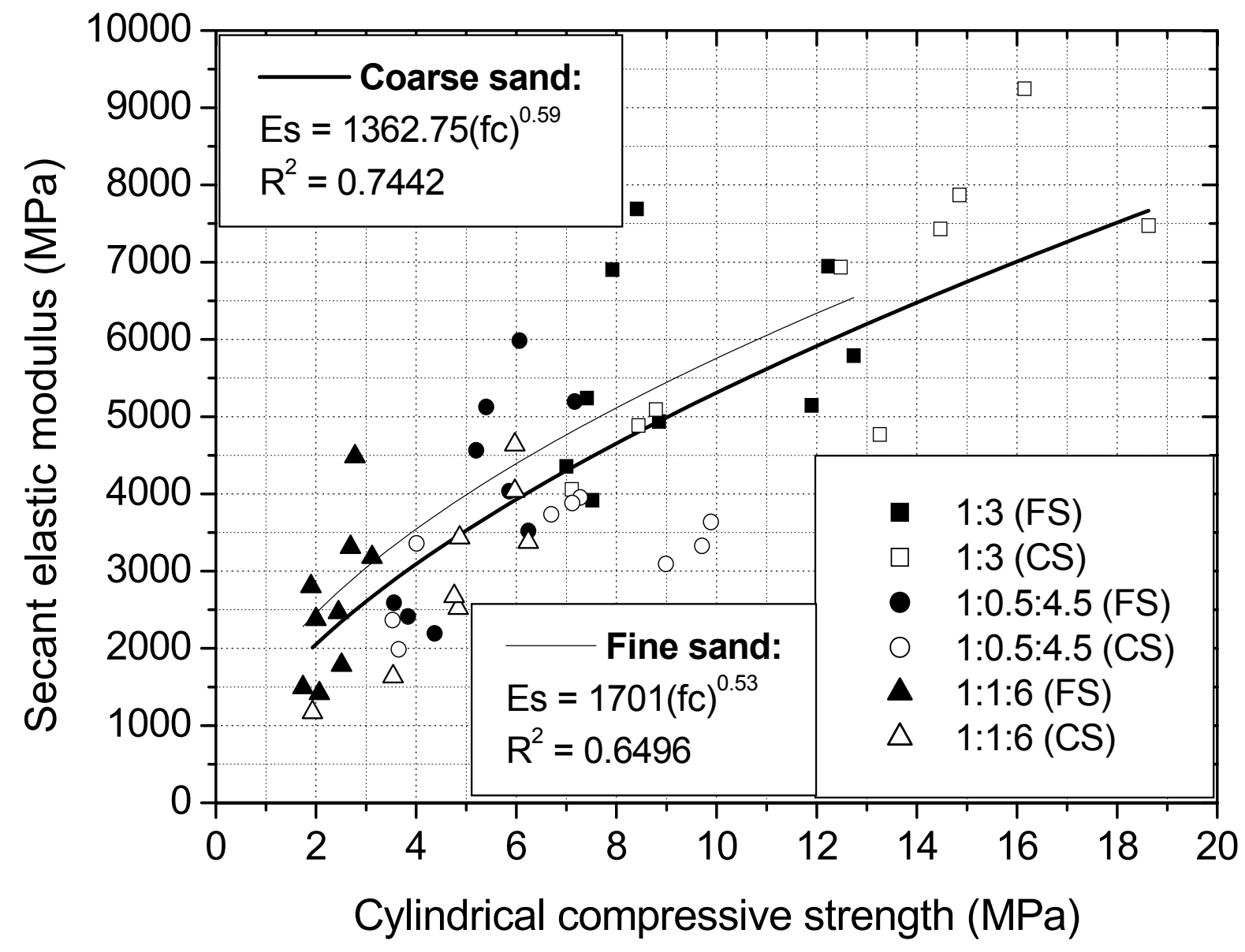




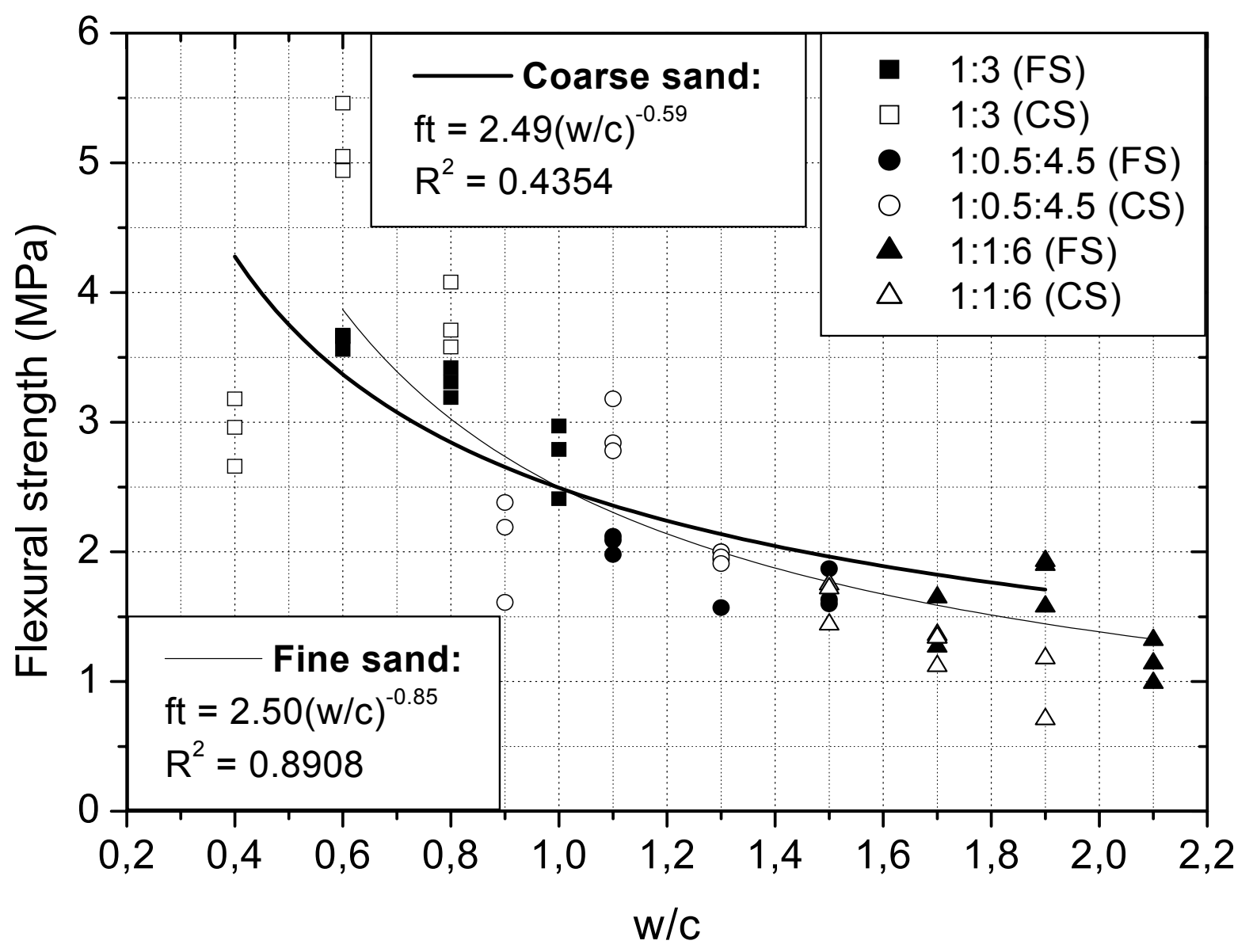




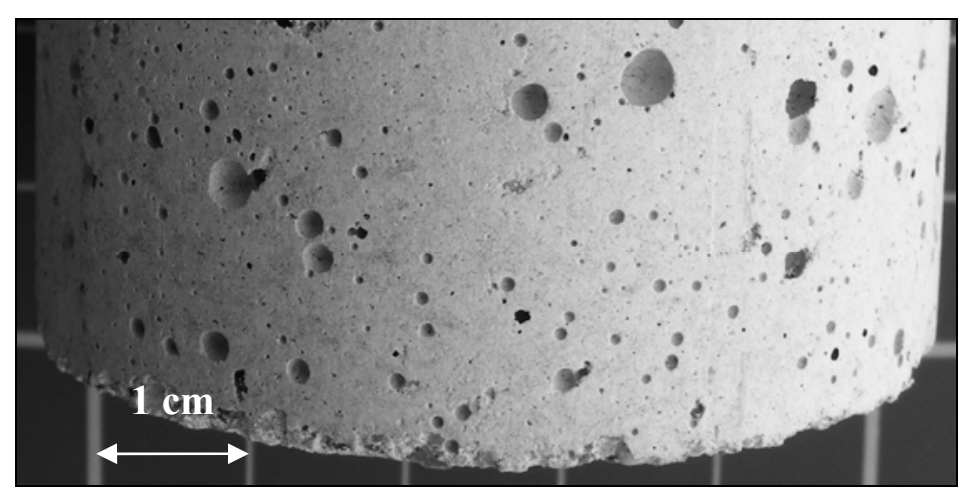

(a)

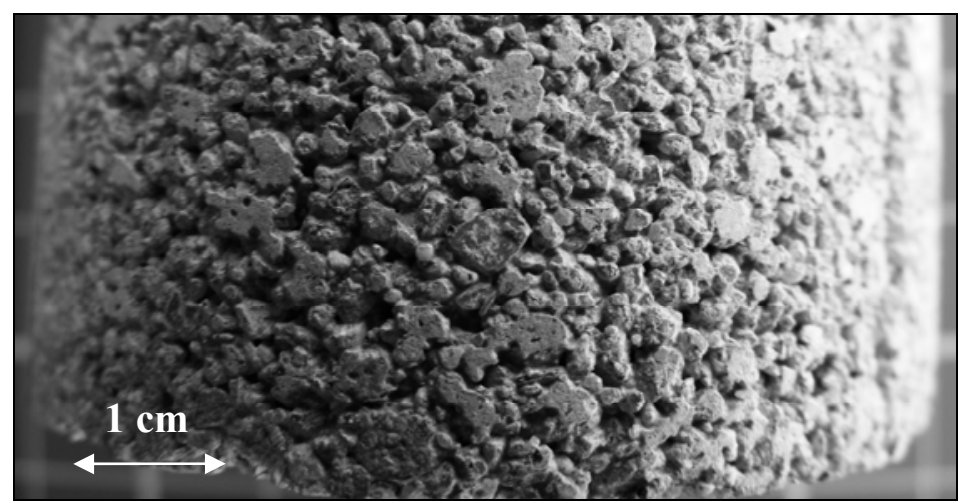

(b) 


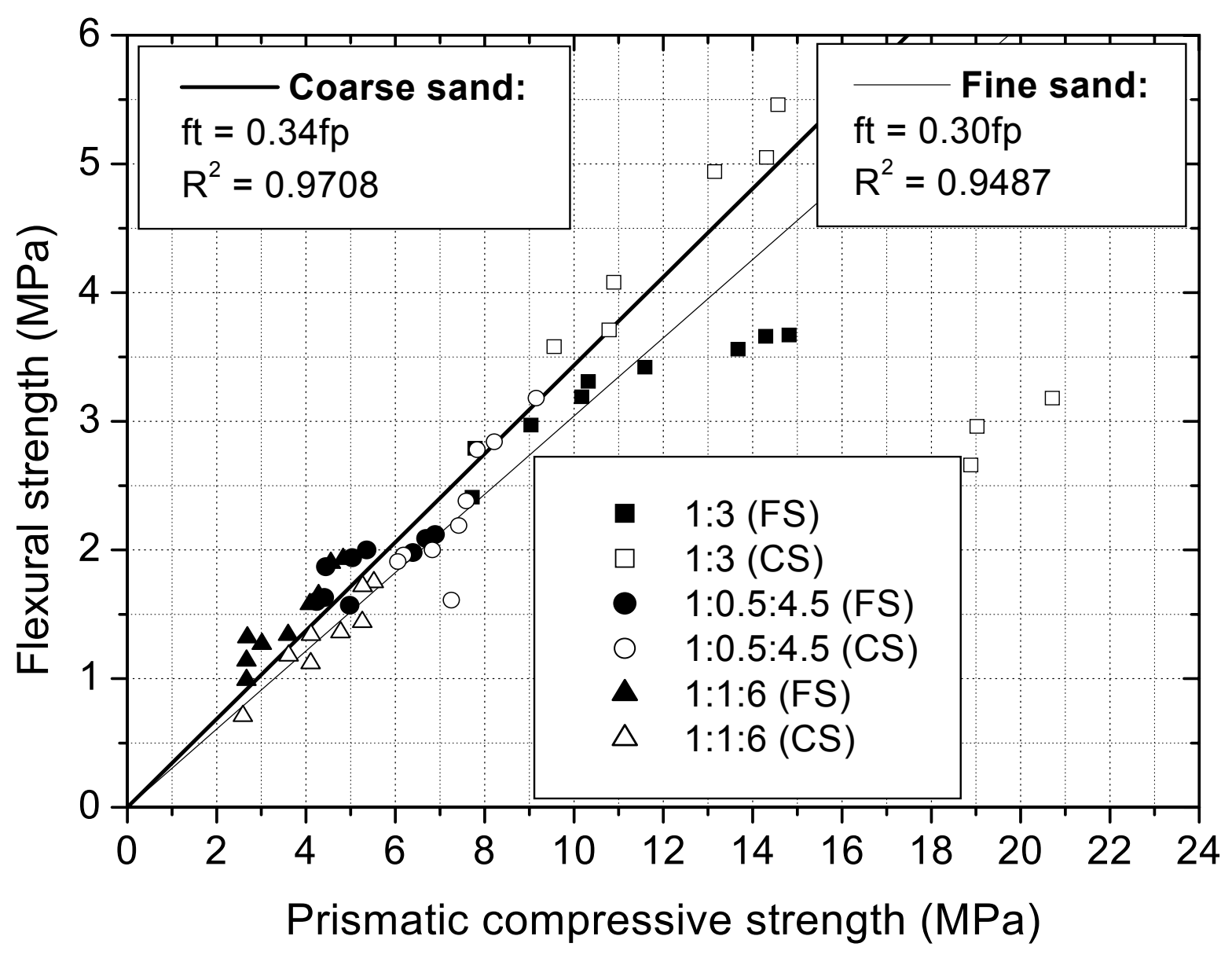

